\title{
ASSESSMENT OF SEXUAL BEHAVIOR AND HABITS OF MEDICAL AND NON-MEDICAL STUDENTS
}

Slobodan Subotić ${ }^{1}$, Biljana Jakovljević ${ }^{2}$, Danijela Radulovic ${ }^{3}$, Ivana Simic Vukomanovic ${ }^{4,5}$ and Vladimir Vukomanovic ${ }^{4}$

${ }^{1}$ College for Health Studies "Milutin Milanković", Belgrade, Serbia

${ }^{2}$ Medical College of applied sciences in Zemun, University of Belgrade, Serbia

${ }^{3}$ Department of primary health care and public health, University of East Sarajevo, Faculty of Medicine Foca, Bosnia and Herzegovina ${ }^{4}$ University of Kragujevac, Faculty of Medical Sciences, Serbia ${ }^{5}$ Institute of Public Health Kragujevac, Serbia

\section{PROCENA SEKSUALNOG PONAŠANJA I NAVIKA STUDENATA MEIDICINSIKE I NEMIEICINSIKE STRUIKE \\ Slobodan Subotić ${ }^{1}$, Biljana Jakovljević2 ${ }^{2}$ Danijela Radulović ${ }^{3}$, Ivana Simić Vukomanović4,5 i Vladimir Vukomanović ${ }^{4}$ ${ }^{1}$ Visoka medicinska škola strukovnoh studija " Milutin Milanković” Beograd ${ }^{2}$ Visoka zdravstvena skola strukovnih studija u Beogradu \\ ${ }^{3}$ Univerzitet u istočnom Sarajevu, Medicinski fakultet Foca, katedra za primarnu zdravstvenu zastitu i javno zdravlje ${ }^{4}$ Univerzitet u Kragujevcu, Srbija, Fakultet medicinskih nauka ${ }^{5}$ Institut za javno zdravlje Kragujevac, Srbija}

Received/Primljen: 01.02.2021.

Accepted/Prihvaćen: 03.02.2021.

\begin{abstract}
Introduction/The aim: The aim of this study is the assessment of sexual behavior and habits of medical and non-medical students in Belgrade. The research is designed as cross-sectional study conducted in the period from November until January 2016/2017. An anonymous and standardized questionnaire from the "National Health Survey" research protocol was used and variables of interest were added. A total of 1268 randomly selected students participated, from higher education institutions in Belgrade (College for Health Studies "Milutin Milankovic, Medical College of applied sciences in Zemun, Belgrade, Business Academy and Faculty of Security Studies in Belgrade). Results: Respondents from both groups almost had sexual relations with the opposite sex, although 2.2\% of students of medical profession and $1.7 \%$ of non-medical profession had sexual relations with the same sex. Condoms are most often contraceptive measures used in both groups, (>40\%). The most common reason for not using condom in both groups were partner's trust or reducing pleasure during intercourse ( $p<0.005$ and $p<0.851$ respectively). Students of non-medical professions comparing to students of medical professions, on the second year of study (7.3\% vs 5.5\%), and on the third year of study (14.1\% vs 2.4\%) stated that the reason for not using a condom is the high cost. Conclusions: According to the obtained results, students of medical professions were prone to risky sexual behaviour, despite greater knowledge about reproductive health and risky sexual behaviors. There is a significant need for an evaluation of educational programs about sexual and reproductive health of students from all orientations.
\end{abstract}

Keywords: students, sexual behavior, habits.

\section{SAŽETAK}

Uvod/cilj: Cilj ove studije je procena seksualnog ponašanja $i$ navika studenta medicinske i nemedicinske struke u Beogradu. Ispitivanje je koncipirano kao studija preseka izvedena u periodu od novembra do januara 2016/2017, godine. Sproveli smo anonimni, standardizovani upitnik iz Protokola istraživanja "National Health Survey” pri čemu su dodate varijable od interesa. Ukupno 1268 slučajno odabranih studenata dobrovoljno su učestvovali u studiji na 4 visoko obrazovane ustanove u Beogradu, (Visoka medicinska škola strukovnih studija "Milutin Milankovic'” u Beogradu, Visoka zdravstvena škola strukovnih studija u Beogradu, Beogradska poslovna škola Visoka škola strukovnih sudija, Fakultet bezbednosti Univerziteta u Beogradu. Rezultati: Ispitanici u obe ispitivane grupe su skoro po pravili stupali u seksualne odnose sa osobama suprotnog pola, ali ipak 2.2\% medicinara $i \quad 1.7 \%$ nemedicinara stupali su u seksualni kontakt sa istopolnim partnerima. Na pitanje koje kontraceptivno sredstvo najčešće koriste, preko 40\% ispitanika se izjasnilo da je u pitanju kondom. Rezultati su pokazali da u obe ispitivane grupe najčešći razlog za ne korišćenje kondoma je to što se osobe izjašnjavaju da veruju svom partneru/partnerki, ili zato što kondom smanjuje užitak tokom seksualnog odnoda (medicinari $p<0.005$; nemedicinari $p<0.851)$. Studenti nemedicinske struke u odnosu na studente medicinske, na drugoj (7.3\% vs. 5.5\%), i trećoj godini studiranja (14.1\% vs. 2.4\%) su se izjasnili da ređe koriste kondom jer je skup. Zaključak: Uzimajući u obzir dobijene rezultate, da su studenti medicinske struke skloni rizičnom seksualnom ponašanju uprkos određenom stepenu znanja $u$ vezi sa reproduktivnim zdravljem kao i u vezi sa rizičnim seksualnim ponašanjem koje su stekli formalnim obrazovanjem, postoji značajna potreba za evaluacijom edukacije u vezi sa seksualnim zdravljem studenata svih usmerenja.

Ključne reči: studenti, seksualno ponašanje, navike. 


\section{INTRODUCTION}

Youth is period of life during which beside biological and psychological maturation, the process of including an individual in the social community also takes place. During studies, society has some expectations from young people, expectations that they will develop skills and abilities which will help them to take significant roles in every part of society (1). Disharmony between biological and psychosocial maturity opens a possibility for risky behaviors which can disturb psychophysical and reproductive health of the adolescent population. Risky sexual behavior of students implies first sexual intercourse at a young age, more frequent partner change, not using contraceptive methods, inconsistent condom use for protection of STI, etc. As a consequence of ignorance, incomplete or inaccurate information, as well as taking reproductive health for granted, there are unwanted pregnancies (usually ending in abortion) or STIs which can have long term consequences on psycho-physical health (2).

Results of the research of health of the population of Serbia in 2013, shows that $33.1 \%$ of young people in Serbia already had sexual intercourse, which is $4.1 \%$ more than showed in the 2006 research. Although an increasing number of young people in the Republic of Serbia follow modern tendencies in sexual behavior, a small number use effective methods of contraception (3).

Young people in the age group of 15-24 years represent $25 \%$ of the sexually active population, and over $60 \%$ of all newly acquired STIs worldwide are registered in this age group (4). Studies show that a great number of young people do not have elementary knowledge about anatomy and physiology of reproduction, and that their knowledge about contraception and STI is poor and filled with prejudice $(5,6)$. One of the important reasons for this kind of behavior is that education of young people about reproductive health for now is not regulated by the system, and because of that the source of knowledge and information for young people are their peers, media as well as the internet. Research in relation to sexual behavior of students shows that students are a highrisk population for acquiring and transmitting STIs (7). Risky sexual behavior of students implies more frequent partner change, entering sexual relations under the effect of psychoactive substances, inconsistent condom use, etc. $(8,9)$. Considering that young people and students are a population that is especially at risk, the attention in the research is mostly focused on their knowledge on risks, significance of preserving reproductive health, use of contraceptive measures, and general knowledge on STIs (10). It is considered that a higher level of knowledge on sexual health provides many benefits to these categories. Promoting knowledge in relation to STIs, as well as developing awareness of all complications and consequences of infections that could occur certainly affects the reduction of risky behavior(10).

\section{THE AIM OF THE PAPER}

The aim of the paper is an assessment of sexual behavior and habits of medical and non-medical students.

\section{PATIENTS AND METHODS}

Research is based on the cross-sectional study and the study population consisted of 1268 students from four higher education institutions of the University of Belgrade of medi$\mathrm{cal}$ and non-medical professions. For the study we used an anonymous and standardized questionnaire from the "National Health Survey" research protocol where variables of interest were added (11).

The sampling method is a stratified (medical / non-medical profession, year of study) random sample. In the research were included the following higher educational institutions of Belgrade University: Medical College of applied sciences in Zemun, Belgrade, College for Health Studies "Milutin Milankovic", Business Academy and Faculty of Security Studies in Belgrade. Respondents were students of medical and non-medical educational profiles.

Prior to the start of the research, the Deans of the selected faculties gave written approval for conducting anonymous surveys. The ethical standards of the research are harmonized with the international (Helsinki Declaration) and specific legislation of our country. In order to respect the privacy of the subject of research and the confidentiality of information, all necessary steps have been taken in accordance with the Law on Personal Data Protection ("Official Gazette of the Republic of Serbia", No. 97/08, 104/09), the Law on Official Statistics ("Official Gazette RS", No. 104/09) and the European Parliament Directive on the protection of personal data with regard to personal data (Directive 95/46 / EC). For conducting the research, the consent of the Ethics Committee of the Faculty of Medical Sciences was obtained.

\section{Statistical analysis}

The complete statistical analysis of data was performed using the statistical software package, PASW Statistics $18 \AA$ [SPSS (Hong Kong) Ltd., Hong Kong]. All variables were presented as the frequency of certain categories. Differences between categorical variables were tested by Chi-square test. The normality of the data was assessed using the Kolmogorov-Smirnov test. The relationship between the variables was tested by Spearman's coefficient correlation. All the analyses were estimated at $\mathrm{p}<0.05$ level of statistical significance.

\section{RESULTS}

Our results show that in answers to the question about having sexual relations there is a significant difference between years of study for students of medical profession $p$ $<0.001$ (Table 1.). The largest number of students who have had sexual relations were on the 3rd year of study (97.3\%), and the smallest number were on the first year $(79.3 \%)$. On the other hand, if we compared the same year of study between students of medical and non-medical profession, results show that on the all the 3 years of study there are more respondents of medical profession who have had sexual 
relations (First year 79.3\% vs. 76.1\%; Second year 90.9\% vs. $74.3 \%$; Third year $97.3 \%$ vs. $82.0 \%$ ).

Respondents from both groups almost as a rule had sexual relations with people of opposite sex, but there are $2.2 \%$ of students of medical profession and $1.7 \%$ of students of nonmedical profession who had sexual relations with people of the same sex.

Regarding the type of sexual intercourse that respondents had, our results show that students of both medical and nonmedical professions more often had all 3 type of sexual intercourse (vaginal, anal and oral) in the third and second year of studies compared to the first year of studies (First year vs. First year: $\mathrm{p}=0.555$; Second year $v s$. Second year: $\mathrm{p}<0.001$; Third year $v s$. Third year: $\mathrm{p}<0.001)$. When we compare students of medical and non-medical profession, results show that oral sex is by $47.5 \%$ and anal sex is by $17.2 \%$ more often practiced by students of non-medical profession and students of medical profession more often practice vaginal sex $97.3 \%$ (Table 1.)

If the frequency of sexual relations is compared, a significant difference can also be observed between students of medical profession relative to the year of study $(p<0.001)$. With a higher year of study there are less students who never had sexual intercourse (First year 20.7\%, Second year 9.1\%; Third year $2.7 \%$ ), and the number of students who had sexual intercourse often increases (First year $40.1 \%$, Second year $44.6 \%$; Third year $55.9 \%$ ). If we compare students of medical and non-medicals professions we find significant differences on the second year of study $(9.1 \%$ vs. $25 \% ; \mathrm{p}<0.001)$, and on the third year of study $(2.7 \%$ vs. $18 \% ; \mathrm{p}<0.001)$.
A significant difference in the use of condoms during vaginal sexual intercourse was found in students of medical professions $(p<0.001)$. Comparing the year of study, with the increase of the year of studying also increased the number of students who never use condoms during vaginal intercourses and decreases the number of those who always use condoms. Comparing students of medical and non-medical professions of the same year of study, results shows that on the second year of study $(16.6 \% \mathrm{vs} .10 .1 \%)$, and on the third year of the study $(24.3 \% \mathrm{vs} .11 .5 \%)$ there are more students of medical professions who participate in unprotected sexual intercourses. Regarding the condom use during anal intercourse, $88.3 \%$ students of medical professions and $64.8 \%$ students of non-medical professions on the third year of study in both groups never had that type of intercourse (Table 2). The results show that students stated that the most common reason for not using condom in both groups were that they trust their partner or that the condom reduces pleasure felt during intercourse (students of medical professions $\mathrm{p}<0.005$; students of non-medical professions $\mathrm{p}<0.851$ ). Students of non-medical professions comparing to students of medical professions, on the second year of study $(7.3 \% v s .5 .5 \%)$, and on the third year of study (14.1\% vs. $2.4 \%)$ stated that the reason for not using a condom is the high cost of condoms (Table 2.).

There are no significant differences about using female condoms. Students of medical professions most often used it in the second year of studies, $4.2 \%$ of them. Regarding the use of contraceptive measures, condoms are most often used in both groups, by over $40 \%$ of subjects. Students of medical professions more commonly use birth control pills (14.7\% vs. $4.0 \%$ ), and coitus interruptus (pull-out method) (27.9\% vs. $9.8 \%$ ) than students of non-medical professions (Table 2).

Table 1. Sexual habits of students

\begin{tabular}{|c|c|c|c|c|c|c|}
\hline Variables & \multicolumn{3}{|c|}{$\begin{array}{c}\text { Medical profession } \\
\text { No } 645\end{array}$} & \multicolumn{3}{|c|}{$\begin{array}{c}\text { Non-medical profession } \\
\text { No } 623\end{array}$} \\
\hline $\begin{array}{l}\text { Did you ever have sexual } \\
\text { relations? }\end{array}$ & I year & II year & III year & I year & II year & III year \\
\hline yes & $\begin{array}{c}180 \\
(79.3)\end{array}$ & $279(90.9)$ & $108(97.3)$ & $175(76.1)$ & $205(74.3)$ & $100(82.0)$ \\
\hline no & $47(20.7)$ & $28(9.1)$ & $3(2.7)$ & $55(23.9)$ & $71(25.7)$ & $22(18.0)$ \\
\hline p value & \multicolumn{3}{|c|}{$<0.001^{*}$} & \multicolumn{3}{|c|}{$0.246^{*}$} \\
\hline \multicolumn{7}{|l|}{$\begin{array}{l}\text { With whom you have } \\
\text { sexual relations: }\end{array}$} \\
\hline $\begin{array}{l}\text { With persons of the oppo- } \\
\text { site sex }\end{array}$ & $\begin{array}{c}225 \\
(99.1) \\
\end{array}$ & $302(98.4)$ & $111(100.0)$ & $225(97.8)$ & $274(99.3)$ & $120(98.4)$ \\
\hline $\begin{array}{l}\text { With persons of the same } \\
\text { sex }\end{array}$ & $2(0.9)$ & $4(1.3)$ & - & $3(1.3)$ & $1(0.4)$ & - \\
\hline With persons of both sex & - & $1(0.3)$ & - & $2(0.9)$ & $1(0.4)$ & $2(1.6)$ \\
\hline p value & \multicolumn{3}{|c|}{$0.623 *$} & \multicolumn{3}{|c|}{$0.343^{*}$} \\
\hline \multicolumn{7}{|l|}{ Oral sexual intercourse } \\
\hline yes & $52(22.9)$ & $91(29.6)$ & $34(30.6)$ & $66(28.7)$ & $112(40.6)$ & $58(47.5)$ \\
\hline no & $\begin{array}{c}175 \\
(77.1) \\
\end{array}$ & $216(70.4)$ & $77(69.4)$ & $164(71.3)$ & $164(59.4)$ & $64(52.5)$ \\
\hline
\end{tabular}




\begin{tabular}{|c|c|c|c|c|c|c|}
\hline Variables & \multicolumn{3}{|c|}{$\begin{array}{c}\text { Medical profession } \\
\text { No } 645 \\
\end{array}$} & \multicolumn{3}{|c|}{$\begin{array}{c}\text { Non-medical profession } \\
\text { No } 623\end{array}$} \\
\hline p value & \multicolumn{3}{|c|}{$0.161^{*}$} & \multicolumn{3}{|c|}{$0.001^{*}$} \\
\hline Anal sexual intercourse & & & & & & \\
\hline yes & $18(7.9)$ & $43(14.0)$ & $11(9,9)$ & $29(12.6)$ & $39(14.1)$ & $21(17.2)$ \\
\hline no & $\begin{array}{c}209 \\
(92.1)\end{array}$ & $264(86.0)$ & $100(90.1)$ & $201(87.4)$ & $237(85.9)$ & $101(82.8)$ \\
\hline p value & \multicolumn{3}{|c|}{$<0.001^{*}$} & \multicolumn{3}{|c|}{$0.241^{*}$} \\
\hline \multicolumn{7}{|c|}{ Vaginal sexual intercourse } \\
\hline yes & $\begin{array}{c}178 \\
(78.4)\end{array}$ & $277(90.2)$ & $108(97.3)$ & $174(75.7)$ & $205(74.3)$ & $100(82.0)$ \\
\hline no & $49(2.6)$ & $30(9.8)$ & $3(2.7)$ & $56(24.3)$ & $71(25.7)$ & $22(18.0)$ \\
\hline p value & \multicolumn{3}{|c|}{$<0.001^{*}$} & \multicolumn{3}{|c|}{$<0.001 *$} \\
\hline \multicolumn{7}{|c|}{ Practicing sexual relations: } \\
\hline Every day & $21(9.3)$ & $22(7.2)$ & $5(4.5)$ & $20(8.7)$ & $21(7.6)$ & $8(6.6)$ \\
\hline $2-3$ times a week & $91(40.1)$ & $137(44.6)$ & $62(55.9)$ & $88(38.3)$ & $103(37.3)$ & $56(45.9)$ \\
\hline $1-3$ times a month & $47(20.7)$ & $93(30.3)$ & $30(27.0)$ & $46(20,0)$ & $52(18.8)$ & $19(15.6)$ \\
\hline Once every three months & $17(7.5)$ & $12(3.9)$ & $6(5.4)$ & $16(7.0)$ & $14(5.1)$ & $10(8.2)$ \\
\hline Once every six months & $3(1.3)$ & $5(1.6)$ & $1(0.9)$ & $6(2.6)$ & $8(2.9)$ & $6(4.9)$ \\
\hline Once a year & $1(0.4)$ & $10(3.3)$ & $4(3.6)$ & $3(1.3)$ & $9(3.3)$ & $1(0.8)$ \\
\hline Never & $47(20.7)$ & $28(9.1)$ & $3(2.7)$ & $51(22.2)$ & $69(25.0)$ & $22(18.0)$ \\
\hline p value & \multicolumn{3}{|c|}{$<0.001^{*}$} & \multicolumn{3}{|c|}{$0.504 *$} \\
\hline
\end{tabular}

Table 2. Condom use and risky sexual behavior of students

\begin{tabular}{|c|c|c|c|c|c|c|}
\hline Variables & \multicolumn{3}{|c|}{$\begin{array}{l}\text { Medical profession } \\
\text { No } 645 \\
\end{array}$} & \multicolumn{3}{|c|}{$\begin{array}{c}\text { Non-medical profession } \\
\text { No } 623 \\
\end{array}$} \\
\hline $\begin{array}{l}\text { Did you ever have sexual } \\
\text { relations? }\end{array}$ & I year & II year & III year & I year & II year & III year \\
\hline yes & $\begin{array}{c}180 \\
(79.3)\end{array}$ & $279(90.9)$ & $108(97.3)$ & $175(76.1)$ & $205(74.3)$ & $100(82.0)$ \\
\hline no & $\begin{array}{c}47 \\
(20.7)\end{array}$ & $28(9.1)$ & $3(2.7)$ & $55(23.9)$ & $71(25.7)$ & $22(18.0)$ \\
\hline p value & \multicolumn{3}{|c|}{$<0.001^{*}$} & \multicolumn{3}{|c|}{$0.246^{*}$} \\
\hline \multicolumn{7}{|l|}{$\begin{array}{l}\text { With whom you have } \\
\text { sexual relations: }\end{array}$} \\
\hline $\begin{array}{l}\text { With persons of the oppo- } \\
\text { site sex }\end{array}$ & $\begin{array}{c}225 \\
(99.1) \\
\end{array}$ & $302(98.4)$ & $111(100.0)$ & $225(97.8)$ & $274(99.3)$ & $120(98.4)$ \\
\hline $\begin{array}{l}\text { With persons of the same } \\
\text { sex }\end{array}$ & $2(0.9)$ & $4(1.3)$ & - & $3(1.3)$ & $1(0.4)$ & - \\
\hline With persons of both sex & - & $1(0.3)$ & - & $2(0.9)$ & $1(0.4)$ & $2(1.6)$ \\
\hline p value & \multicolumn{3}{|c|}{$0.623^{*}$} & \multicolumn{3}{|c|}{$0.343^{*}$} \\
\hline \multicolumn{7}{|l|}{ Oral sexual intercourse } \\
\hline yes & $\begin{array}{c}52 \\
(22.9)\end{array}$ & $91(29.6)$ & $34(30.6)$ & $66(28.7)$ & $112(40.6)$ & $58(47.5)$ \\
\hline no & $\begin{array}{c}175 \\
(77.1)\end{array}$ & $216(70.4)$ & $77(69.4)$ & $164(71.3)$ & $164(59.4)$ & $64(52.5)$ \\
\hline p value & \multicolumn{3}{|c|}{$0.161 *$} & \multicolumn{3}{|c|}{$0.001 *$} \\
\hline
\end{tabular}




\begin{tabular}{|c|c|c|c|c|c|c|}
\hline \multirow{2}{*}{$\begin{array}{c}\text { Variables } \\
\text { Anal sexual intercourse }\end{array}$} & \multicolumn{3}{|c|}{$\begin{array}{l}\text { Medical profession } \\
\text { No } 645\end{array}$} & \multicolumn{3}{|c|}{$\begin{array}{c}\text { Non-medical profession } \\
\text { No } 623 \\
\end{array}$} \\
\hline & & & & & & \\
\hline yes & $18(7.9)$ & $43(14.0)$ & $11(9,9)$ & $29(12.6)$ & $39(14.1)$ & $21(17.2)$ \\
\hline no & $\begin{array}{c}209 \\
(92.1)\end{array}$ & $264(86.0)$ & $100(90.1)$ & $201(87.4)$ & $237(85.9)$ & $101(82.8)$ \\
\hline p value & \multicolumn{3}{|c|}{$<0.001 *$} & \multicolumn{3}{|c|}{$0.241 *$} \\
\hline \multicolumn{7}{|c|}{ Vaginal sexual intercourse } \\
\hline yes & $\begin{array}{c}178 \\
(78.4)\end{array}$ & $277(90.2)$ & $108(97.3)$ & $174(75.7)$ & $205(74.3)$ & $100(82.0)$ \\
\hline no & $49(2.6)$ & $30(9.8)$ & $3(2.7)$ & $56(24.3)$ & $71(25.7)$ & $22(18.0)$ \\
\hline p value & \multicolumn{3}{|c|}{$<0.001^{*}$} & \multicolumn{3}{|c|}{$<0.001^{*}$} \\
\hline \multicolumn{7}{|c|}{ Practicing sexual relations: } \\
\hline Every day & $21(9.3)$ & $22(7.2)$ & $5(4.5)$ & $20(8.7)$ & $21(7.6)$ & $8(6.6)$ \\
\hline 2-3 times a week & $91(40.1)$ & $137(44.6)$ & $62(55.9)$ & $88(38.3)$ & $103(37.3)$ & $56(45.9)$ \\
\hline $1-3$ times a month & $47(20.7)$ & $93(30.3)$ & $30(27.0)$ & $46(20,0)$ & $52(18.8)$ & $19(15.6)$ \\
\hline Once every three months & $17(7.5)$ & $12(3.9)$ & $6(5.4)$ & $16(7.0)$ & $14(5.1)$ & $10(8.2)$ \\
\hline Once every six months & $3(1.3)$ & $5(1.6)$ & $1(0.9)$ & $6(2.6)$ & $8(2.9)$ & $6(4.9)$ \\
\hline Once a year & $1(0.4)$ & $10(3.3)$ & $4(3.6)$ & $3(1.3)$ & $9(3.3)$ & $1(0.8)$ \\
\hline Never & 47 (20.7) & $28(9.1)$ & $3(2.7)$ & $51(22.2)$ & $69(25.0)$ & $22(18.0)$ \\
\hline p value & \multicolumn{3}{|c|}{$<0.001 *$} & \multicolumn{3}{|c|}{$0.504 *$} \\
\hline
\end{tabular}

*Chi-square test

No-number.

\section{DISCUSSION}

Sexual behavior varies from one society to another depending on race, ethnicity, gender and socio-economic status. The average age of the first sexual intercourse varies in most countries. In highly developed countries more that $50 \%$ of adolescents had already had their first sexual intercourse at the age from 15 to 18 years old. Unfortunately, in many countries there is no comprehensive sex education program for this age group (12).

Students who had attended programs of sexual education more often use contraceptives. Some of them get information about sexual health and contraceptives from their friends, television and health workers. Comparing the knowledge and sexual practice among students of different areas of education, it has been noticed that students of some medical sciences show healthier behavior than other students (13).

In a study performed at the University in Palermo among students of medical professions most students, over $75.31 \%$ of them, already had some sexual experience (14). In our study, students of medical professions had significantly more sexual intercourses than students from Italy, while students of non-medical professions in our study had approximately the same percentage of sexual intercourse. In our study same as in study from Palermo, most students were from the first year of study and the least from the third (14).
Most subjects in our study were of heterosexual orientation, which is confirmed by the study from Italy where also the most subjects were of heterosexual orientation, and a lesser number of subjects were of homosexual orientation ( $p$ $=0.213)$ and bisexual orientation $(p=0.166)(14)$. As for the types of sexual intercourse that are practiced, students of the University from Brasil, just as students from our study, mostly practiced vaginal and oral sexual intercourses. (15).

Unlike the study from Spain where every other students had sexual intercourse 1-2 times per week, in our study the most common answer about sexual frequency is 2-3 times per week (13).

Concerning the condom use during sexual intercourses, students from our study as well as students from the studies from other Universities from Europe and from the world, show that, despite the level of knowledge about risky sexual behaviour, still only consider vaginal sexual intercourse as the most risky type of sexual intercourse during which they use condoms.

Research from the University of California among students of medical professions shows that condoms were used mostly during vaginal sexual intercourse $48.5 \%$, then anal $26.0 \%$, and least in oral intercourse $6.2 \%$ (16). Research from Italy among students of medical professions shows that more than $92 \%$ of students do not use condoms during oral sexual intercourse (17). 
Students from the department of Kinesiology in Texas, during anal sexual intercourses use sometimes or rarely condoms, with a higher number of sexual partners condom use is declining, 1 partner $18.8 \%, 2-4$ partners $5.4 \%$, and over 5 partners $1.7 \%(18)$.

As in the above mentioned studies, in our study a high percentage of students almost never use a condom during oral intercourse, while during vaginal intercourse most adhere to measures of prevention and safe sex. Despite the risks of unprotected sex, students are replacing condom use with other forms of contraception.

The reasons of not using a condom, in first and last year of study from the research from University from Croatia, is using others types of contracepties, while our students from all years of study stated that they trust their partners (19).

Unlike the study done in Congo, where a large percentage of respondents, over $80 \%$ had experience with the use of female condoms, in our study we have the opposite situation where over $90 \%$ of students had never used a female condom (20).

A study from Spain shows that regarding the use of contraceptive measures the most commonly used was the hormone therapy used by a quarter of respondents, while $3.6 \%$ used emergency contraception, every fifth postcoital pill, and $2.6 \%$ of them had legal abortion (13). While our respondents, in addition to the condom, which is in the first place as the main type of contraception, also use hormonal pills and interrupted intercourse, while during oral and anal sexual intercourse, condoms are never used to a large extent.

\section{CONCLUSION}

This study describes sexual habits and risky sexual behavior among students of medical and non-medical professions from Universities in Serbia. Student of medical professions are prone to risky sexual behavior despite a certain level of knowledge about reproductive health and risky sexual behavior which they acquired during formal education. Based on the results of the study, there is a significant need to evaluate education related to student sexual health. Young people should receive adequate education from professionals, and not gather knowledge from the internet, friends and other non professional sources of information. There is a need to introduce sex education programs in high schools as well as universities. We also believe that it is necessary to introduce education for young people who do not attend universities and thus provide them with an adequate level of information.

Based on previous research as well as relevant data related to uterine cancer, which is extremely widespread on the territory of the Republic of Serbia, and is significantly related to the risky sexual behavior of young people, all of the above should be taken into consideration and preventive educational programs should be started intensively.

\section{CONFLICT OF INTEREST}

None.

\section{REFERENCES}

1. Simić Vukomanović I. Procena mentalnog zdravlja i prevencija mentalnih poremećaja studentske populacije (disertacija). Kragujevac: Fakultet medicinskih nauka Univerziteta u Kragujevcu, 2016.

2. Simić Vukomanović I, Đukić A, Kocić S, Zdravković N, Radević S, Đukić S. Povezanost hroničnih nezaraznih bolesti i reproduktivnog zdravlja u populaciji žena centralne Srbije (STEPwise Approach)" - praktikum. Kragujevac: Fakultet medicinskih nauka Univerziteta u Kragujevcu, 2020.

3. Istraživanje zdravlja stanovništva Srbije u 2013. Republika Srbija Ministarstvo zdravlja, Institut za javno zdravlje Srbije „Dr Milan Jovanović Batut“ Beograd, 2014.

4. Centers for Disease Control and Prevention. Sexually Transmitted Disease Surveillance 2018. STDs in Adolescents and Young Adults.

5. Available at: https://www.cdc.gov/std/stats18/adolescents.htm

6. Noraziah M, Ismarulyusda I ,Manoharan K. Knowledge, attitude and practice towards sexually transmitted diseases amongst the inmates of women shelters homes at Klang Valley. BMC Public Health. 2019; 19(4): 639.

7. Baptista $A D$, Simão $C X$, Santos VCGD, Melgaço JG, Cavalcanti SMB, Fonseca SC, Vitral CL. Knowledge of human papillomavirus and Pap test among Brazilian university students. Rev Assoc Med Bras 2019; 65(5):625632.

8. Benson T, Ellis J. High risk sexual behavior and reasons for living in college students. J Psychol Psychother, 2019; Vol. 9 Iss. 3 No: 361

9. Lori J, Sheldon S, Carey M, Carey K. Alcohol and Risky Sexual Behavior among Heavy Drinking College Students. AIDS Behav. 2010; 14(4): 845-853.

10. Chanakira E, Cathain A. Factors perceived to influence risky sexual behaviours among university students in the United Kingdom: a qualitative telephone interview study. BMC Public Health. 2014; (14):1055, 2-7.

11. Weinstein RB, Walsh JL, Ward LM. Testing a new measure of sexual health knowledge and its connections to students' sex education, communication, confidence, and condom use. Int J Sex Health. 2008; 19;20(3):21221.

12. Publications Office of the European Union, 2013. European Health Interview Survey (EHIS wave 2) Methodological manual. Available at: https://ec.europa.eu/eurostat/documents/3859598/5926729/KS-RA-13-018EN.PDF/26c7ea80-01d8-420e-bdc6-e9d5f6578e7c

13. Warzecha D, Szymusik I, Pietrzak B, Kosinska-Kaczynska K, Sierdzinski J, Sochacki-Wojcicka N, Wielgos M. Sex education in Poland -across-sectional study 
evaluating over twenty thousand polish women's knowledge of reproductive health issues and contraceptive methods. BMC Public Health. 2019; 19(1):689.

14. Leon-Larios F, Macías-Seda J. Factors related to healthy sexual and contraceptive behaviors in undergraduate students at university of Seville: a cross- sectional study. Reprod Health. 2017; 14(1):179.

15. Provenzano S, Santangelo OE, Terranova A, D'Anna G, Grigis D, Firenze A. Investigate the sexual habits of young people: a cross-sectional study among nursing students of the University of Palermo. Acta Biomedic. 2020; 91(2-S):50-7.

16. Caetano ME, Linhares IM, Pinotti JA, da Fonseca AM, Wojitani MD, Giraldo PC. Sexual behavior and knowledge of sexually transmitted infections among university students in Sao Paulo, Brazil. Int J Sex Health. 2010; 110(1):43-6.

17. Trieu SL, Bratton S, Hopp Marshak H. Sexual and reproductive health behaviors of California community college students. J Am Coll Health. 2011; 1;59(8):74450 .

18. Santangelo OE, Provenzano S, Firenze A. Knowledge of sexually transmitted infections and sex-at-risk among
Italian students of health professions. Data from a onemonth survey. Ann Ist Super Sanita. 2018; 29;54(1):408.

19. Fehr SK, Vidourek RA, King KA, Nabors LA. Relationship Factors' Impact on Condom Use Among College Students. Sexuality \& Culture. 2018; 1;22(3):724-39.

20. Burazin J, Kožul K, Miškulin M, Dijanić T, Medić A, Jurčev-Savičević A. Sexual behaviour and condom use as a protection against sexually transmitted infections in student population. Coll. antropol 2014; 31;38(1):31-7.

21. Bernard MM. Evaluation of female condom use among students at the university of Lubumbashi: Knowledge, attitude and practice on university cities. Open Access Library Journal. (2017);4(11):1. 